\title{
Guiding Stem Cell Differentiation and Proliferation Activities Based on Nanometer-Thick Functionalized Poly-p-Xylylene Coatings
}

\author{
Chih-Yu Wu ${ }^{1,2,3, \dagger}$, Yu-Chih Chiang ${ }^{3,4,+}{ }^{+}$Jane Christy ${ }^{1}$, Abel Po-Hao Huang ${ }^{4,5}$, Nai-Yun Chang ${ }^{1}$, Wenny ${ }^{1}$, \\ Yu-Chih Chiu ${ }^{6}$, Yen-Ching Yang ${ }^{1}$, Po-Chun Chen ${ }^{6, *}$, Peng-Yuan Wang ${ }^{7,8, *}$ and Hsien-Yeh Chen ${ }^{1,2,3, *(1)}$
}

Citation: Wu, C.-Y.; Chiang, Y.-C.; Christy, J.; Huang, A.P.-H.; Chang, N.-Y.; Wenny; Chiu, Y.-C.; Yang, Y.-C.; Chen, P.-C.; Wang, P.-Y.; et al. Guiding Stem Cell Differentiation and Proliferation Activities Based on Nanometer-Thick Functionalized Poly- $p$-Xylylene Coatings. Coatings 2021, 11, 582. https://doi.org/10.3390/ coatings11050582

Academic Editor: Alenka Vesel

Received: 23 March 2021

Accepted: 12 May 2021

Published: 17 May 2021

Publisher's Note: MDPI stays neutral with regard to jurisdictional claims in published maps and institutional affiliations.

Copyright: (c) 2021 by the authors. Licensee MDPI, Basel, Switzerland. This article is an open access article distributed under the terms and conditions of the Creative Commons Attribution (CC BY) license (https:// creativecommons.org/licenses/by/ $4.0 /)$.
1 Department of Chemical Engineering, National Taiwan University, Taipei 10617, Taiwan; picorna.tw@yahoo.com.tw (C.-Y.W.); b07504085@ntu.edu.tw (J.C.); Changnaiyun@ntu.edu.tw (N.-Y.C.); r06524094@ntu.edu.tw (W.); youngeddie@cgmh.org.tw (Y.-C.Y.)

2 Advanced Research Center for Green Materials Science and Technology, National Taiwan University, Taipei 10617, Taiwan

3 Molecular Imaging Center, National Taiwan University, Taipei 10617, Taiwan; munichiang@ntu.edu.tw

4 School of Dentistry, Graduate Institute of Clinical Dentistry, National Taiwan University, Taipei 10048, Taiwan; howhuang6138@ntu.edu.tw

5 Division of Neurosurgery, Department of Surgery, National Taiwan University Hospital, Taipei 10048, Taiwan

6 Department of Materials and Mineral Resources Engineering, National Taipei University of Technology, Taipei 10608, Taiwan; t107788007@ntut.edu.tw

7 Center for Human Tissues and Organs Degeneration, Institute of Biomedicine and Biotechnology, Shenzhen Institutes of Advanced Technology, Chinese Academy of Sciences, Shenzhen 518055, China

8 Department of Chemistry and Biotechnology, Swinburne University of Technology, Melbourne, VIC 3122, Australia

* Correspondence: cpc@mail.ntut.edu.tw (P.-C.C.); py.wang@siat.ac.cn (P.-Y.W.); hsychen@ntu.edu.tw (H.-Y.C.); Tel.: +886-2-33669476 (H.-Y.C.); Fax: +886-2-23623040 (H.-Y.C.)

+ Chih-Yu Wu and Yu-Chih Chiang contributed equally to this work.

Abstract: Modifications of biomaterials based on the combination of physical, chemical, and biological cues for manipulating stem cell growth are needed for modern regenerative medicine. The exploitation of these sophisticated modifications remains a challenge, including substrate limitation, biocompatibility, and versatile and general cues for stem cell activities. In this report, a vapor-phase coating technique based on the functionalization of poly- $p$-xylylene (PPX) was used to generate a surface modification for use with stem cells in culture. The coating provided the ability for covalent conjugation that immobilized bone morphogenetic protein 2 (BMP-2) and fibroblast growth factor 2 (FGF-2), and the modified coating surfaces enabled direct stem cell differentiation and controlled proliferation because of the specific activities. The ligations were realized between the growth factors and the maleimide-modified surface, and the conjugation reactions proceeded with high specificity and rapid kinetics under mild conditions. The conjugation densities were approximately $140 \mathrm{ng} \cdot \mathrm{cm}^{-2}$ for BMP-2 and $155 \mathrm{ng} \cdot \mathrm{cm}^{-2}$ for FGF-2. Guiding the activities of the human adipose-derived stem cells (hADSCs) was achieved by modifying surfaces to promote the hADSC differentiation capacity and proliferation rate. The reported coating system demonstrated biocompatibility, substrate-independent conformity, and stability, and it could provide an effective and versatile interface platform for further use in biomedical applications.

Keywords: growth factor; surface modification; CVD polymerization; biointerface; stem cells

\section{Introduction}

Surface properties are fundamental to advanced biomaterials that are designed to induce biological functions, and they include tuning surface wettability; the ability to enhance or to resist protein adsorption, cell adhesion or resistance; antibacterial action; and engineered niches for stem cell proliferation, migration, and differentiation [1-5]. In particular, sophisticated applications of these modification techniques that make stem 
cells renew themselves and retain their potency (i.e., the capability to differentiate into specialized cell types) [6,7] are under development. Promising results of unlimited cell expansion or lineage-specific differentiation in a reproducible and controlled manner and efficient and controlled differentiation commitment of specific cells and tissues were achieved in vitro and in vivo with combinations of mimicked physical, chemical, and/or biological cues [8-10]. Emerging therapeutic uses, encouraged by the advances in modern regenerative medicine, have also benefited from these promising results from research on stem cells used for tissue transplantation and repair. The current obstacles to achieving sophisticated material modifications include the potential harm from substances used during the process, the need for multiple steps to achieve the required sophistication, and techniques that are based on previous performance in a case-by-case manner and with a limited selection of materials.

The study herein aims to demonstrate an effective and general interface modification method for use in defining stem cell fate and enhancing the functions related to proliferation rate and multilineage differentiation capacity. The proposed modification technique was realized by the functionalization of poly- $p$-xylylene that includes a maleimide side group. The functional polymer was synthesized as an interface layer generated in one vapor-phase coating process and applied to the material surface through the exploitation of a chemical vapor deposition (CVD) polymerization process used to prepare maleimide-functionalized poly- $p$-xylylene (hereafter referred to as maleimide-PPX) coatings. Compared to other similar poly- $p$-xylylene systems, this technology, free of solvents, initiators, and catalysts, produced a coating that exhibited good conformability with the topology and geometry of substrates [11-13] with excellent cohesive properties and thermal stability on various substrates, including metals, oxides, polymers, nonvolatile liquids, silicon, and glass [12]. Most importantly, in the current study, conjugation-immobilized (i) bone morphogenetic protein 2 (BMP-2) and (ii) fibroblast growth factor 2 (FGF-2) enabled the modified coating surfaces to direct stem cell differentiation and controlled proliferation driven by the functions specified by (i) and (ii), respectively. The resulting BMP-2- and FGF-2-modified substrates were expected to be sustainable and multifunctional, so that they could provide an effective and flexible interface platform for biomedical applications.

\section{Materials and Methods}

\subsection{CVD Surface Modifications}

The synthesis of the coating, poly[(4-N-maleimidomethyl-p-xylylene)-co(p-xylylene)] (maleimide-PPX), was conducted by a custom-built CVD system (Kao Duen Technology Co., Ltd., Taipei, Taiwan) consisting of a sublimation zone, pyrolysis furnace, and deposition chamber. During the CVD process, the starting material (dimer) of 4-N-maleimidomethyl[2.2]paracyclophane, which was prepared following procedures reported elsewhere [14], was first sublimated at approximately $120^{\circ} \mathrm{C}$ in the sublimation zone. The sublimated species were then transferred to the pyrolysis furnace $\left(560{ }^{\circ} \mathrm{C}\right)$ with a constant flow (30-50 sccm) of argon carrier gas. Following pyrolysis, the resulting highly reactive monomers were transferred into the deposition chamber and polymerized onto a rotating holder at $20^{\circ} \mathrm{C}$ to form a uniformly deposited film of maleimide-PPX. To optimize the deposition, a pressure of 75 mTorr was maintained throughout the CVD process, and deposition rates were controlled at approximately $0.5 \AA \cdot \mathrm{s}^{-1}$, which was monitored via an in-situ quartz crystal microbalance (STM-100/MF, Sycon Instruments, Syracuse, NY, USA). The thickness of the polymer layer was measured as approximately 100-150 nm by using spectroscopic ellipsometry (M2000, Woollam Co., Inc., Lincoln, NE, USA) after retrieving the coated samples from the CVD system. The resultant polymer coating was also characterized by using Fourier transform infrared (FT-IR, PerkinElmer, Waltham, MA, USA) and X-ray photoelectron spectroscopy (XPS, Thermo Scientific, Leicestershire, UK) to verify the anticipated chemical compositions. 


\subsection{Growth Factor Immobilization}

Selected human recombinant growth factors, including BMP-2 and FGF-2, were obtained commercially from R\&D Systems Inc. (Minneapolis, MN, USA) and reconstituted into a $100 \mu \mathrm{g} \cdot \mathrm{mL}^{-1}$ solution following the manufacturer's instructions. These two growth factors were then conjugated to the maleimide-PPX coated substrates via a coupling reaction between the maleimide and the thiol (sulfhydryl) groups under conditions of $4{ }^{\circ} \mathrm{C}$ and pH 6.5-7.5 for $6 \mathrm{~h}$. Dithiothreitol (DTT, Sigma Aldrich, St. Louis, MO, USA) (5 mM) was used as a reducing agent for the BMP-2 and FGF-2 immobilization. A rinsing process was performed three times with PBS to remove any unbound molecules.

\subsection{Characterizations}

FT-IR spectra were recorded using a spectrum 100 FT-IR spectrometer (PerkinElmer, Waltham, MA, USA) equipped with an advanced grazing angle specular reflectance accessory (AGA, PIKE Technologies, Fitchburg, WI, USA) and a liquid nitrogen-cooled MCT detector. The samples were mounted in a nitrogen-purged chamber to eliminate noise from the $\mathrm{CO}_{2}$ and $\mathrm{H}_{2} \mathrm{O}$, and the recorded spectra were corrected for any residual baseline drift. The XPS data were recorded using a Theta Probe X-ray photoelectron spectrometer (Thermal Scientific, Leicestershire, UK) with a monochromatized AlK $\alpha$ X-ray source at an $\mathrm{X}$-ray power of $150 \mathrm{~kW}$. The pass energies were $200.0 \mathrm{eV}$ and $20.0 \mathrm{eV}$ for the survey scan and the high-resolution $C_{1 s}$ elemental scan, respectively. The XPS spectrum atomic analysis was reported based on atomic concentrations (\%), and the results were compared to theoretical values calculated based on the structure. The binding capacities of the modified surfaces for the growth factor protein were measured using a standard QCM instrument (ANT Technologies, Taipei, Taiwan) with a quiescent mode under sealed conditions, and the measuring of the deposited protein mass was based on the fundamental frequency shift as compared with unbinding or unmodified surfaces. For the antibody affinity experiments performed by flow mode, the QCM instrument was further equipped with a flow injection analysis (FIA) device (MasterFlex, Cole-Parmer Instrument Co., Chicago, IL, USA), and a continuous frequency variation recording device was used for the characterization. The flow rate was controlled using a peristaltic pump connected to the FIA device, and the pumping process was temporarily stopped for $25 \mathrm{~min}$ (10 min after injection) to allow anti-BMP-2 or anti-FGF-2 antibodies to bind to the proteins. All experiments were carried out at $25^{\circ} \mathrm{C}$, and each sample was measured in triplicate. The frequency shift $\Delta \mathrm{F}$ resulting of a deposited mass $\Delta \mathrm{m}$ is described by the Sauerbrey equation [15]:

$$
\Delta \mathrm{F}=\frac{-2 \Delta m f^{2}}{A \sqrt{\mu \rho_{q}}}=-C_{f} \Delta m
$$

where $f$ is the intrinsic crystal frequency $(9 \mathrm{MHz}), A$ is the piezo-electrically active area $\left(0.091 \mathrm{~cm}^{2}\right), \rho_{q}$ is the quartz crystal density $\left(2.648 \mathrm{~g} / \mathrm{cm}^{3}\right), \mu$ is the shear modulus of the quartz crystals $\left(2.947 \times 1011 \mathrm{dyn} / \mathrm{cm}^{2}\right), C_{f}$ is the mass sensitivity $(2.013 \mathrm{~Hz} / \mathrm{ng}$ for a $9 \mathrm{MHz}$ crystal), and $\Delta \mathrm{m}$ is the adding mass on the crystal surface due to specific binding, respectively.

\section{4. $\mu \mathrm{CP}$ and Immunofluorescence}

Confinement of the reactions using $\mu \mathrm{CP}$ was performed using two different poly(dimethylsiloxane) (PDMS) stamps consisting of squares with $30 \mu \mathrm{m} \times 30 \mu \mathrm{m}$ sides (for BMP-2) and $50 \mu \mathrm{m} \times 50 \mu \mathrm{m}$ sides (for FGF-2) and arrays with $100 \mu \mathrm{m}$ center-center spacing. Solutions with the growth factor proteins (BMP-2 or FGF-2) were used as the inking solutions and allowed to react on top of the maleimide-PPX-modified substrates for $6 \mathrm{~h}$. The $\mu \mathrm{CP}$ process was performed at $4{ }^{\circ} \mathrm{C}$ and $55 \%$ humidity. The resulting sample was washed twice with PBS to remove any unbound molecules. For the self-assembled binding of the primary and secondary antibodies, the BMP-2- and FGF-2-modified samples were incubated in the corresponding antibody solution, anti-BMP-2 antibody $\left(50 \mu \mathrm{g} \cdot \mathrm{mL}^{-1}\right.$ in PBS, R\&D Systems, Minneapolis, MN, USA) or anti-FGF-2 antibody (50 $\mu \mathrm{g} \cdot \mathrm{mL}^{-1}$ in PBS, 
R\&D Systems, Minneapolis, MN, USA), for $2 \mathrm{~h}$, and the samples were washed twice with PBS to remove any unbound antibodies. Subsequently, fluorescently labeled secondary antibodies were incubated with the samples for $1 \mathrm{~h}$ and washed twice with PBS to remove any unbound antibodies. The samples with fluorescence signals were analyzed under a LEICA fluorescence microscope (DMI3000B, Leica Microsystems, Wetzlar, Germany).

\subsection{Induced Cellular Activities}

Tissue culture polystyrene (TCPS) plate substrates ( 24 well, Corning) were modified with a CVD copolymer coating and conjugated with BMP-2 or FGF-2 growth factor proteins following the procedures described above, and the modified TCPS plates were used for cell culture experiments. The pure maleimide-PPX coating surface and the untreated TCPS plate surface served as controls for the comparison. Normal human adipose-derived stem cells (hADSCs) were isolated from subcutaneous adipose tissue following the reported procedures [13], and the protocols were approved by the Internal Ethical Committee of National Taiwan University Hospital. To evaluate differentiation and proliferation activities, the hADSC cultures were initially seeded at a density of $1 \times 10^{5}$ cells $\cdot \mathrm{cm}^{-2}$ and $2 \times 10^{4}$ cells $\cdot \mathrm{cm}^{-2}$, respectively, for the following characterization. Each experiment was conducted in triplicate.

\subsection{Osteogenesis}

Osteogenic differentiation-induced activity was examined by culturing hADSCs in osteogenic differentiation medium [16]. The osteogenic activity of early stage alkaline phosphatase (ALP) expression was analyzed using a 5-Bromo-4-Chloro-3-Indolyl Phosphate / Nitroblue Tetrazolium (BCIP/NBT) liquid substrate system (Sigma-Aldrich, St. Louis, MO, USA) at day 10, whereas the late stage osteogenic activity, as indicated by calcium deposition, was confirmed by staining with a $2 \%$ alizarin red S solution (ARS, Sigma Aldrich, St. Louis, MO, USA) at day 21 . The resulting ALP and ARS signals were quantitatively measured using a microplate spectrophotometer (BioTek Instruments, Winooski, VT, USA) with an absorbance wavelength of $405 \mathrm{~nm}$ following the manufacturer's instructions.

\subsection{Chondrogenesis}

Chondrogenic differentiation-induced activity was examined in chondrogenic differentiation medium [16] for 14 days. The cultured cells were fixed in 10\% formalin (Macron Fine Chemicals, Center Valley, PA, USA), and the proteoglycan present in the cartilage matrix was detected by staining with $0.4 \%(w / v)$ toluidine blue O (Sigma-Aldrich) in $0.1 \mathrm{M}$ sodium acetate buffer ( $\mathrm{pH}$ 4.0). The sulfated glycosaminoglycan (sGAG) content was further analyzed by using a 1,9-dimethylmethylene blue (DMMB, Sigma-Aldrich) dye-binding spectrophotometric assay, and quantification was based on the absorbance difference between 525 and $595 \mathrm{~nm}$ [17]. The expression profiles of the chondrogenesis-related gene encoding collagen type II were also analyzed.

\subsection{Adipogenesis}

For the analysis of adipogenic differentiation induced activity, hADSCs were cultured in adipogenic differentiation medium [16]. On day 10, the cells were fixed with $10 \%$ formalin and then stained with $0.25 \%(w / v)$ oil red O (Sigma-Aldrich) to observe lipid droplets. The resulting oil red $\mathrm{O}$ signals were further quantified using a microplate spectrophotometer (BioTek Instruments, Winooski, VT, USA) with an absorbance wavelength of $510 \mathrm{~nm}$ following the protocol reported [18]. The expression profiles of the adipogenic gene Fatty Acid-Binding Protein 4 (FABP-4) were also analyzed.

\subsection{Proliferation Activities}

To judge proliferation activities, a cell growth medium recipe and culture conditions were used as previously described [19]. After culturing with cells for 1 day and 5 days, the resulting cultured sample surfaces were observed and photographed using an opti- 
cal microscope to determine cell proliferation levels. The cell numbers for the studied surfaces were further measured quantitatively using a 3-(4,5-Dimethylthiazol-2-yl)-2,5diphenyltetrazolium Bromide (MTT) assay (Sigma-Aldrich) according to the manufacturer's instructions. The normalized ratio of cells on day 5 to cells on day 1 was used to evaluate the cell proliferation-induced capacities of the modified surfaces.

\subsection{Gene Expression Profiles}

The gene expression levels were determined by quantitative real-time polymerase chain reaction (qPCR) analysis following the manufacturer's protocols. Briefly, total RNA from the hADSCs and differentiated cells was extracted with TRIzol reagent (Thermo Fisher Scientific, Waltham, MA, USA), and then the RNA concentration was determined using a NanoDrop ND-1000 spectrophotometer (Thermo Fisher Scientific). Complementary DNA (cDNA) was synthesized subsequently from the RNA template using a high-capacity cDNA reverse transcription kit (Thermo Fisher Scientific). Gene expression level was analyzed using a StepOnePlus ${ }^{\text {TM }}$ Real-Time PCR System (Thermo Fisher Scientific) with gene-specific primers (as indicated in Table 1 ), and the $\beta$-actin was used as a loading control to normalize the expression of the target gene(s) between different samples. The thermal program for PCR was as follows: 35 cycles of $94{ }^{\circ} \mathrm{C}$ for $30 \mathrm{~s} ; 60{ }^{\circ} \mathrm{C}$ for $30 \mathrm{~s}$; and $72{ }^{\circ} \mathrm{C}$ for $1 \mathrm{~min}$ followed by incubation at $72^{\circ} \mathrm{C}$ for $5 \mathrm{~min}$. The fold changes in gene expression were calculated with the delta-delta $\mathrm{Ct}$ method [20].

Table 1. PCR primer sets used in this study.

\begin{tabular}{ccc}
\hline $\begin{array}{c}\text { Gene } \\
\text { Name }\end{array}$ & $\begin{array}{c}\text { Primer } \\
\text { Sequence }\left(\mathbf{5}^{\prime}-\mathbf{3}^{\prime}\right)\end{array}$ & $\begin{array}{c}\text { Product } \\
\text { Length } \mathbf{( b p )}\end{array}$ \\
\hline $\begin{array}{c}\text { Collagen } \\
\text { type II }\end{array}$ & $\begin{array}{c}\text { Forward- ACG GCG AGA AGG GAG AAG TTG } \\
\text { Reverse- GGG GGT CCA GGG TTG CCA TTG }\end{array}$ & 352 \\
FABP-4 & $\begin{array}{c}\text { Forward- TGG GCC AGG AAT TTG ACG AA } \\
\text { Reverse- GAC GCA TTC CAC CAC CAG TT } \\
\text { Forward- CAG GAG ATG GCC ACT GCC GCA } \\
\text { Reverse- TCC TTC TGC ATC CTG TCA GCA }\end{array}$ & 158 \\
\hline
\end{tabular}

\subsection{Statistical Analysis}

All data are reported as the mean \pm standard deviation (S.D.) and are representative of three or more independent experiments. According to the unpaired $t$-test, GraphPad Prism 7 software (GraphPad Software, Inc., San Diego, CA, USA) was used to test the statistical differences between the experimental group and the control group, and a two-tailed $p$-value less than 0.05 was considered significant.

\section{Results}

The synthesis of the maleimide-PPX coating was conducted similarly to that of other poly- $p$-xylylene (PPX) systems; that is, a precursor of a maleimide-substituted [2.2]paracyclophane (prepared in-house) [21] was sublimated at approximately $120^{\circ} \mathrm{C}$ and pyrolyzed at approximately $560{ }^{\circ} \mathrm{C}$ to generate reactive monomers of quinodimethane. The entire process involved vapor-phase deposition and polymerization (chemical vapor deposition, CVD) under a reduced pressure of $75 \mathrm{mTorr}$, and a deposition rate of approximately 0.5-1.0 $\AA \cdot \mathrm{s}^{-1}$ was regulated during the CVD process with a linear-dependent time theoretical parameter $[22,23]$ that was controlled to ensure that the final coating thickness was in the range of 100-150 nm. As shown in Figure 1a, the rational maleimide functionality enabled the resultant coating to readily undergo a maleimide-thiol coupling reaction to the target molecules that contain thiols through a Michael-type nucleophilic addition at $\mathrm{pH}$ 6.5-7.5 [14], and successful conjugation created through this reaction to attach protein molecules without compromising protein structures and functions has been shown [24]. The important application of using maleimide-PPX to conjugate FGF-2 and BMP-2 growth factor proteins was therefore exploited under mild reaction conditions. The successful 
conjugation was confirmed by comparing the Fourier transform infrared (FT-IR) spectra with those of a pure maleimide-PPX coating, and the characteristic absorption values of $\mathrm{N}-\mathrm{H}$ peaks in the range from 3200 to $3600 \mathrm{~cm}^{-1}$, which represent the immobilized FGF-2 and BMP-2 proteins, were detected (Figure 1b). The additional FT-IR spectra that comparing maleimide-PPX surface with parylene- $C$ surface combined with the $X$-ray photoelectron spectroscopy (XPS) survey to verify the anticipated chemical compositions of the maleimide-PPX coating are included in Supplementary Figure S1. Most importantly, the FT-IR spectra showing the thiol groups of BMP-2 and FGF-2 proteins (i.e., the S-H band at $2634 \mathrm{~cm}^{-1}$ ) were highlighted in Supplementary Figure S2. After conjugating BMP-2 and FGF-2 to the coating surface, the S-H peak disappeared (see Figure 1). This result proved that the two adhesion cues BMP-2 and FGF-2 are covalently bonded to the coating surface.

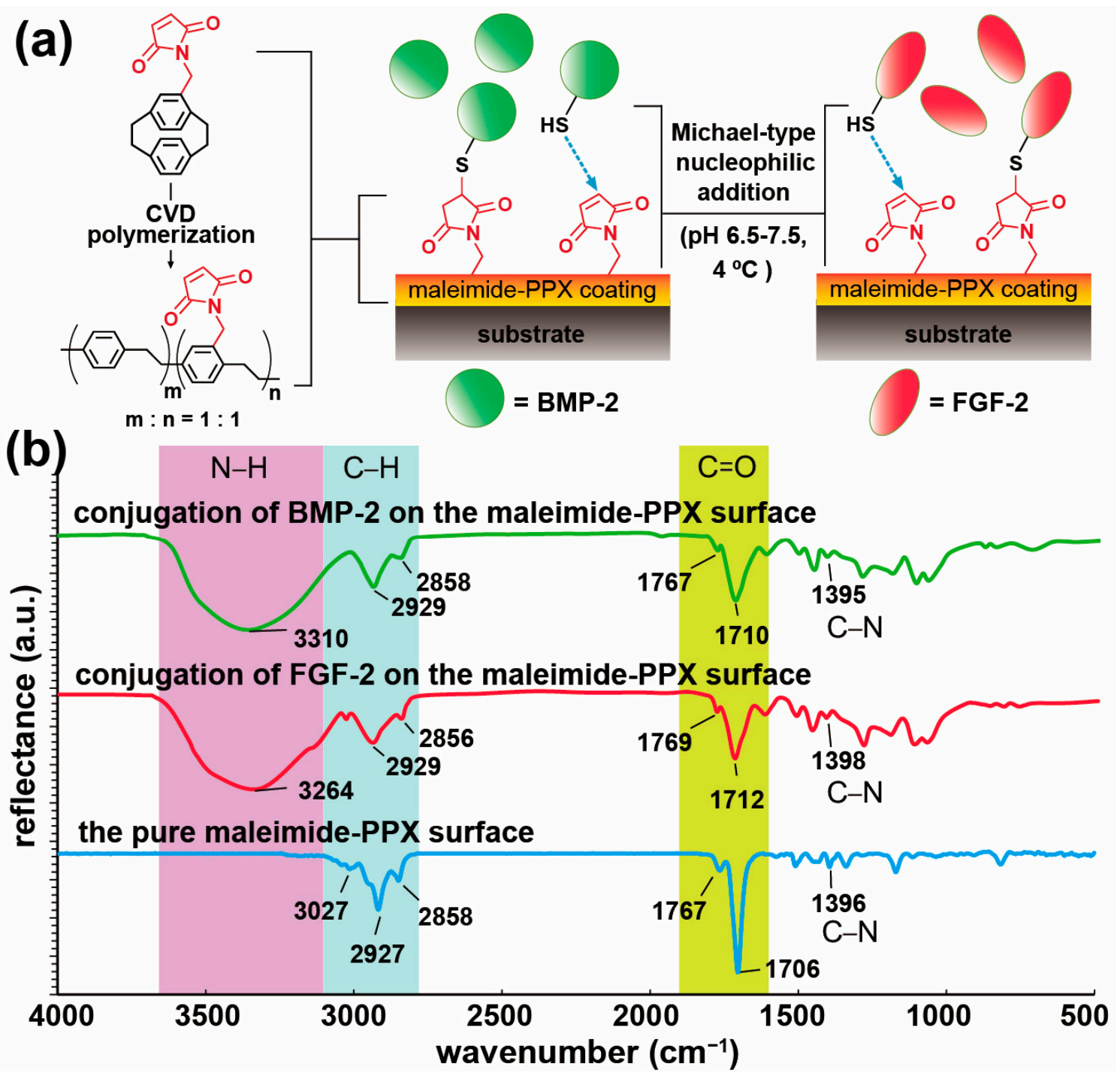

Figure 1. (a) Schematic illustration of the created cell differentiation-induced surfaces using the maleimide-PPX coating to immobilize the BMP-2 and FGF-2 growth factor proteins. (b) FT-IR spectra show the immobilized BMP-2 and FGF-2 on the maleimide-PPX surface. The peaks in the range from $3200 \mathrm{~cm}^{-1}$ to $3600 \mathrm{~cm}^{-1}$ indicate the characteristic $\mathrm{N}-\mathrm{H}$ band absorption of BMP-2 and FGF-2. FT-IR spectra of the pure maleimide-PPX surfaces are also presented for comparison. The peaks located at $1396 \mathrm{~cm}^{-1}(\mathrm{C}-\mathrm{N})$ and $1706 \mathrm{~cm}^{-1}(\mathrm{C}=\mathrm{O})$ correspond to the characteristic stretching bands for the maleimide groups.

Furthermore, the generation of the maleimide-PPX coating and the subsequent conjugation of FGF-2 and BMP-2 were seamlessly performed on a quartz crystal microbalance (QCM) sensor chip, and the recorded frequencies before and after conjugation were com- 
pared to estimate the density of conjugated FGF-2 and BMP-2, which was thus determined as approximately $140 \mathrm{ng} \cdot \mathrm{cm}^{-2}$ for BMP-2 and $155 \mathrm{ng} \cdot \mathrm{cm}^{-2}$ for FGF-2 (Figure 2a). These results showed agreement with other similar PPX systems that have been used to attach biomolecules. Theoretically, the conjugation density is tunable, and the effectiveness of the resultant biological activities is predictable [25]. On the other hand, as presented in Figure 2b, a dynamic QCM analysis in which anti-BMP-2 or anti-FGF-2 antibodies could bind to the modified surfaces was performed in the elapsed time, and the results indicated significantly decreasing frequencies due to the binding of anti-BMP-2 antibody and antiFGF-2 antibody on the BMP-2-modified and the FGF-2-modified coatings, respectively, compared to the nearly unchanged frequencies on the pure coating surfaces. Notably, the small frequency drop in the pure coating study cannot be considered as expected antibody-antigen specific bonding, because this reduction level of frequency may be due to the limitations of the QCM equipment and the measurement errors caused by random fluctuations in the experimental phase [26]. The results not only confirmed the identity and activity of the immobilized FGF-2 and BMP-2 proteins but also indicated a firm attachment of these proteins by covalent conjugation, which was also found by the abovementioned FT-IR data. Other supporting data were used to verify the reactivity and specificity of the immobilized FGF-2 and BMP-2 surfaces. As shown in Figure 2c, they were derived from the use of a microcontact printing $(\mu \mathrm{CP})$ technique with a PDMS stamp to induce a selective reaction with BMP-2 and FGF-2 at confined locations of the maleimide-PPX coating surfaces. Subsequently, solutions with a primary antibody and a fluorescently labeled secondary antibody (fluorescein for the BMP-2 secondary antibody and Alexa Fluor ${ }^{\circledR} 555$ for the FGF-2 secondary antibody) were incubated with these selectively modified samples, and the combined self-assembled bindings between the growth factor proteins and these antibodies showed strong, distinguishable fluorescence signals in the green channel with fluorescein on the BMP-2-modified regions and in the red channel by Alexa Fluor ${ }^{\circledR} 555$ on the FGF-2 regions. These patterns were consistent with those from the $\mu C P$ stamps. The specific binding affinities of the two growth factor proteins were unambiguously verified.
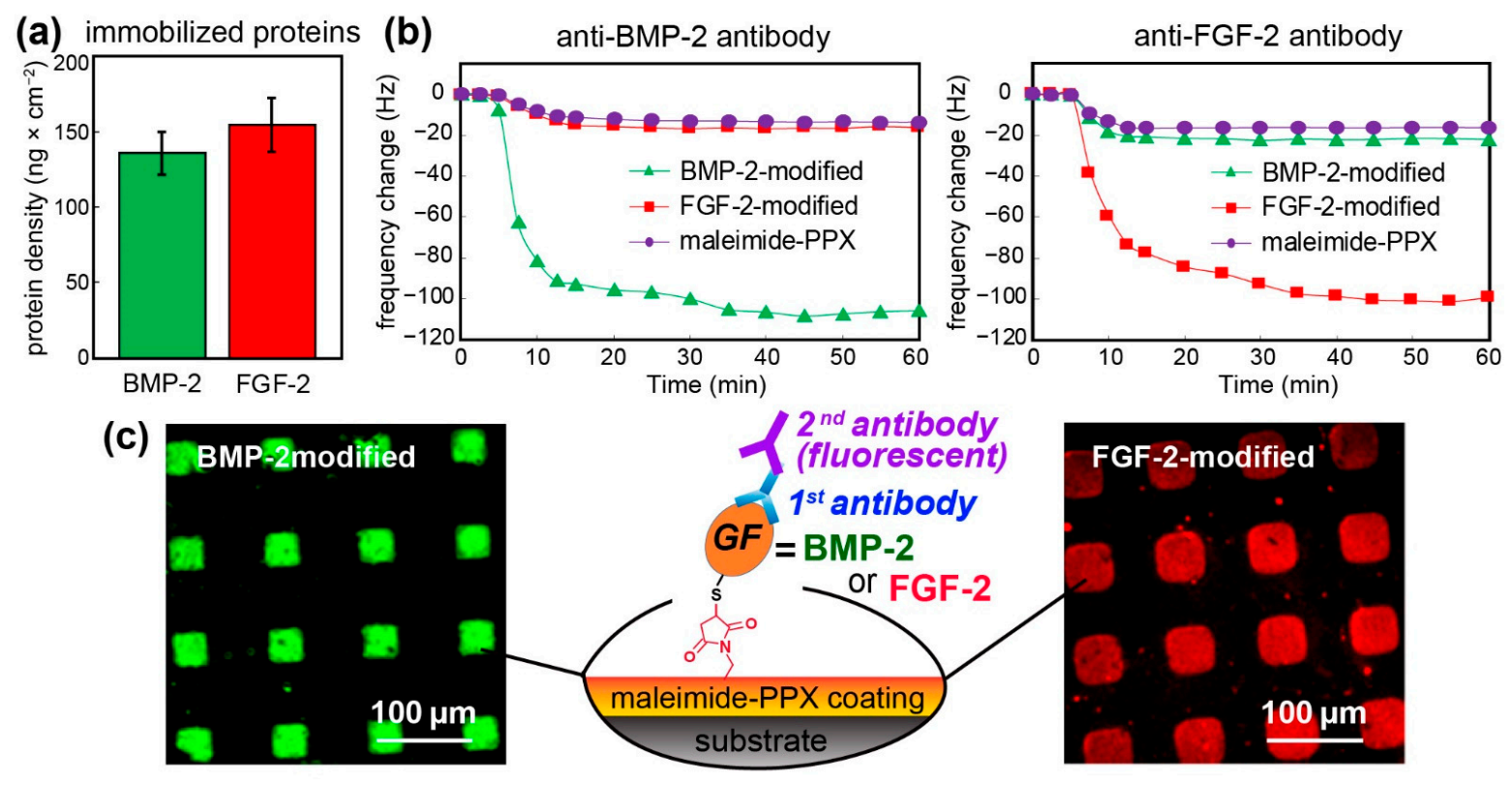

Figure 2. (a) Quantification of the conjugation densities of BMP-2 and FGF-2 by using QCM analysis. (b) QCM dynamic analysis of the binding affinity of the studied surfaces toward anti-BMP-2 and anti-FGF-2 antibodies. (c) The activity and specificity of the immobilized growth factors were verified by exploiting a $\mu \mathrm{CP}$ technique to spatially confine the conjugation of BMP-2 and FGF-2 to defined locations. Combinations of self-assembled binding affinities by first antibodies (anti-BMP-2 and anti-FGF-2) and by secondary antibodies (fluorescently labeled secondary antibodies) show that the fluorescence patterns are consistent with the $\mu \mathrm{CP}$ patterns. 
The induction of these hADSCs toward osteogenic differentiation was studied by examining their alkaline phosphatase (ALP) expression in the early stage and alizarin red staining (ARS) in the mature stage of osteogenesis, and the results in Figure 3a indicated the enhanced ALP expression at day 10 on the modified surfaces of BMP-2 compared to the expression levels on the control surfaces consisting of pure maleimide-PPX and unmodified tissue culture polystyrene (TCPS) plates. Similar results from experiments on enriched calcium deposition, as evaluated by ARS signals at day 21, were also observed for the BMP-2 surfaces. Statistical analysis of these ALP and ARS signals, shown in Figure $3 b, c$, further confirm the enhanced osteogenesis on the growth factor-modified surface ${ }^{* * *} p<0.001$ relative to the control surfaces). The BMP-2-modified surface had a greater level of osteogenesis activity signal expression, with a $276.9 \%$ higher intensity compared to the lowest level, which was for the TCPS control surface. Furthermore, the hADSC activity toward chondrogenic differentiation was investigated on those surfaces by detecting the known mechanism and characteristic indications of chondrogenesis, as determined at day 14 by (i) staining and characterizing the color and intensity changes caused by the metachromatic binding between toluidine blue and cartilage polysaccharides, (ii) sulfate glycosaminoglycan (sGAG) deposition, and (iii) collagen type II expression. The results presented in Figure $4 \mathrm{a}-\mathrm{c}$ reveal that the intensities and signals for (i), (ii), and (iii) were all consistently greater on the BMP-2-modified surface than they were on the other surfaces $(* * *<0.001)$, indicating that chondrogenesis was best enhanced on this modified surface among those studied.

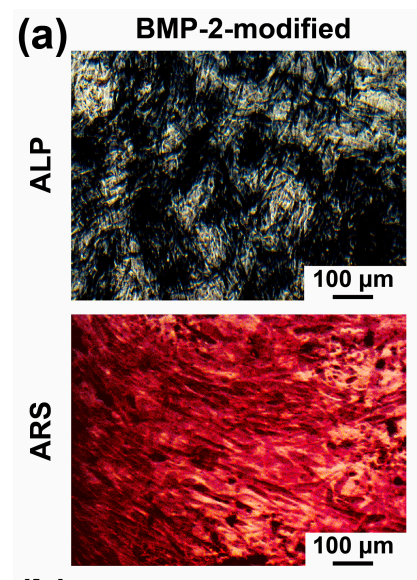

(b)

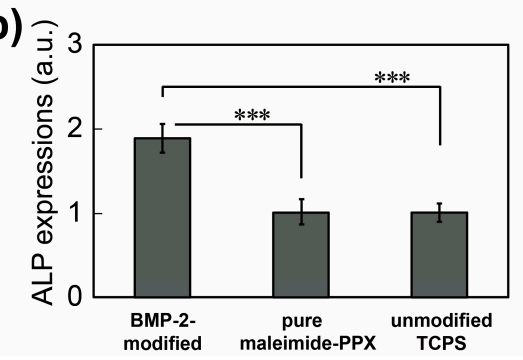

pure maleimide - PPX

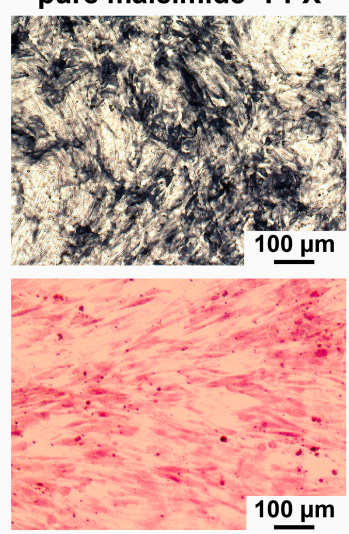

(c)

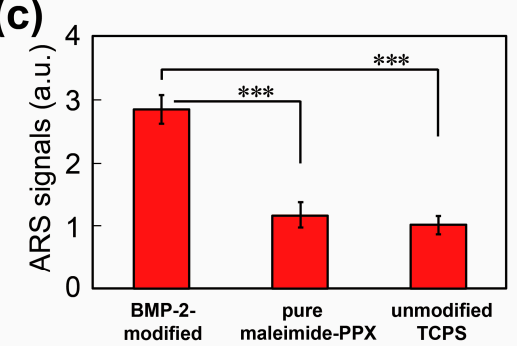

Figure 3. The osteogenesis activities of hADSCs were examined on the modified surfaces with immobilized BMP-2 growth factor protein. Pure maleimide-PPX coating surfaces and unmodified tissue culture polystyrene (TCPS) surfaces were used for the comparison. (a) The early stage osteogenesis marker, ALP expression, was analyzed at day 10, and the mature stage marker, calcium deposition, was observed at day 21 using alizarin red staining (ARS). The results of statistical analyses of the quantified (b) ALP signals and (c) ARS signals were also compared for the studied surfaces. The data bars represent the mean value $(n=3)$ and the standard deviation $( \pm S D)$ based on three independent experiments. The significance level ${ }^{* * *}$ stands for ${ }^{* * *} p<0.001$, and is shown by the results of the unpaired $t$-test. 
(a)

pure maleimide -PPX unmodified TCPS

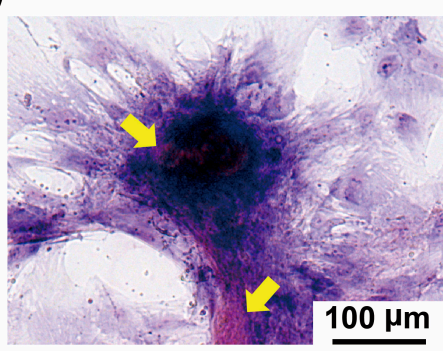

(b)

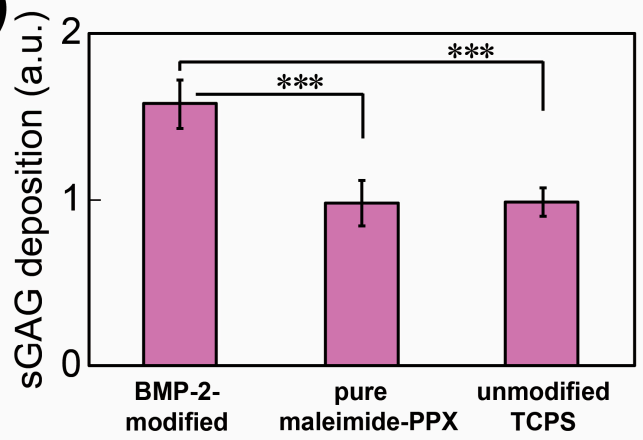

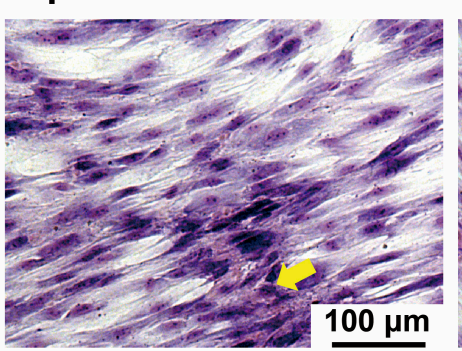

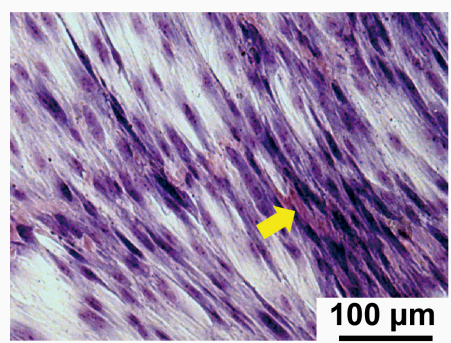

(c)

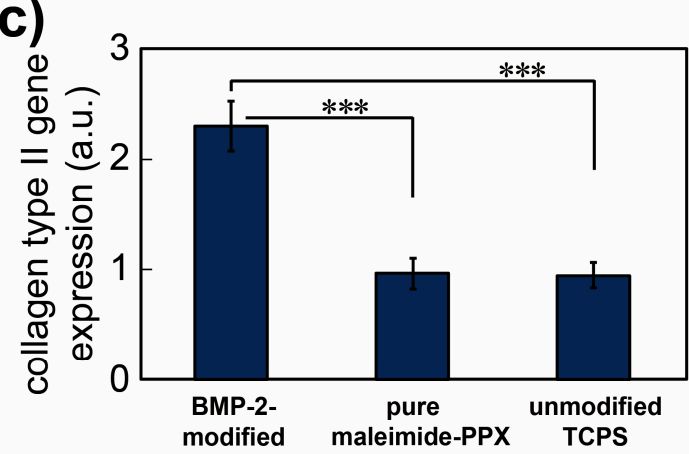

Figure 4. Chondrogenic activities of hADSCs were examined on the studied surfaces. (a) Toluidine blue staining was performed on day 14 to trigger the metachromatic color change (yellow arrows). The detected intensities from (b) sulfated glycosaminoglycan (sGAG) by using a spectrophotometric 1,9-dimethylmethylene blue (DMMB) dye binding assay and (c) the chondrogenic marker collagen type II gene expression by quantitative PCR analysis were statistically analyzed and compared for the studied surfaces. The data bars represent the mean value $(n=3)$ and the standard deviation $( \pm S D)$ based on three independent experiments. The significance level ${ }^{* * *}$ stands for ${ }^{* * *} p<0.001$, and is shown by the results of the unpaired $t$-test.

Furthermore, the adipogenic induction of hADSCs on the modified coating surfaces was analyzed by observing the light-refraction of lipid droplets, which accumulate during adipogenesis, within the differentiated cells at day 10. A characteristic staining technique in which oil red $\mathrm{O}$ dye binds to lipids was used to visualize the lipid droplets (Figure 5a). In addition, $172.3 \%$ increases in adipogenesis activity based on quantitative oil red $\mathrm{O}$ staining were confirmed for the FGF-2-modified surfaces, significant difference (*** $p<0.001$ ) compared to that for other surfaces (Figure $5 b$ ), and the expression of the FABP-4 gene was detected (Figure 5c), further supporting the quantitative results. Finally, in another demonstration, the functions that determine stem cell action, as based on the use of the growth factor-modified coating, were examined by culturing normal human adipose-derived stem cells (hADSCs) on the modified surfaces. As displayed in Figure 6, the analysis by using phase-contrast microscopy and MTT assay revealed high biocompatibility for cell growth (data are included in Supplementary Figure S3) and reflected a consistent level of cell adhesion for all the studied surfaces on day 1 (Figure 6a,b). Notably, significant variation was discovered between these surfaces over an extended culture time frame such that, at day 5, the FGF-2-modified surfaces specifically exhibited profound proliferation of hADSCs compared to that of the pure maleimide-PPX coating surface and unmodified TCPS surface (Figure 6a,b). Statistically, the proliferation ratio of cell number that was normalized by day 5 to day 1 unambiguously revealed the anticipated results by showing an approximate $377.8 \%$ higher ratio for the FGF-2-modified surfaces, a significant difference $\left.{ }^{* * *} p<0.001\right)$ compared to that for other surfaces, and the enhanced hADSC proliferation activity from using the growth factor-modified coating technique was also evident (Figure 6c). 

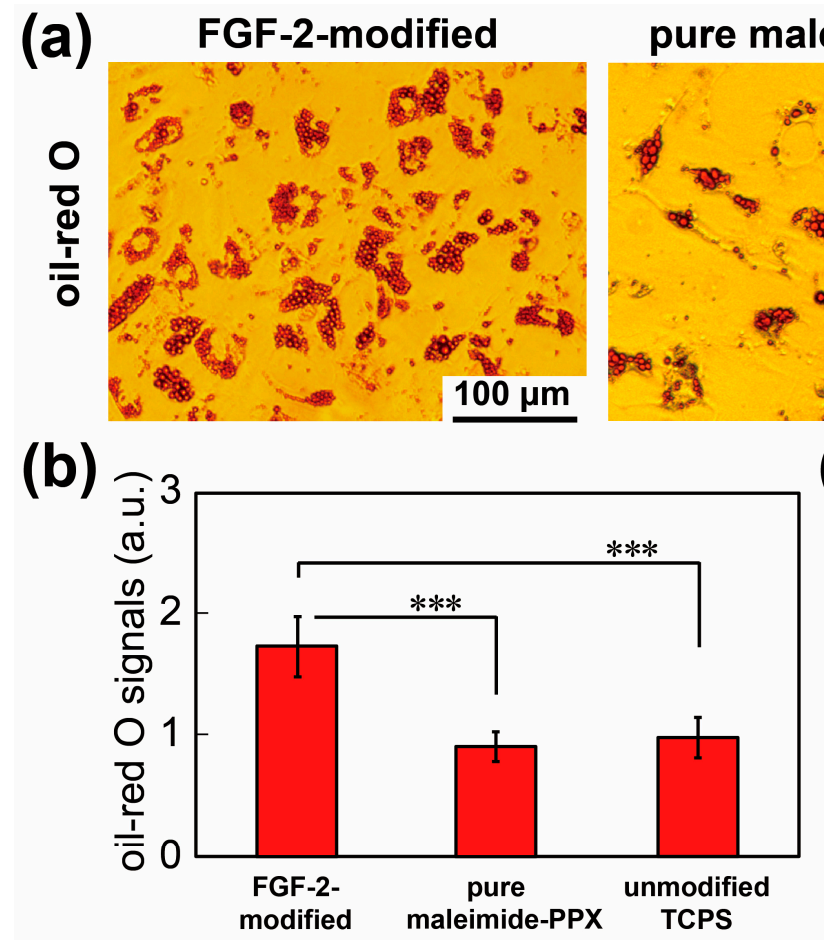

pure maleimide - PPX

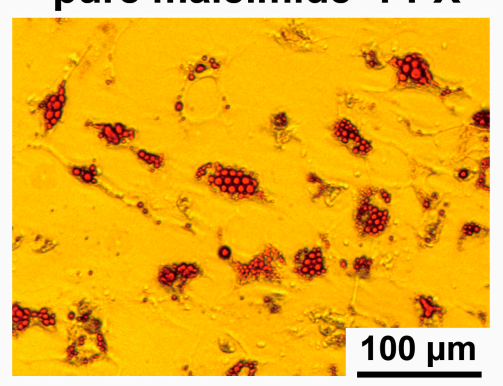

(c)

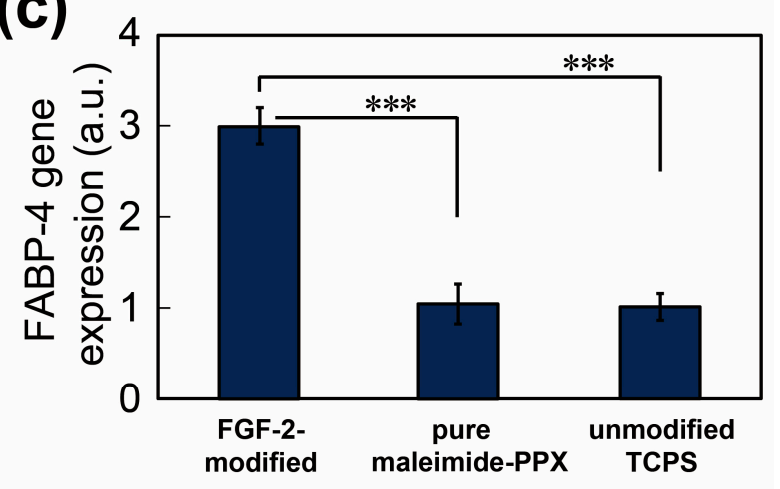

Figure 5. The adipogenic activities of the hADSCs were examined on the studied surfaces. (a) Recorded oil-red O staining images of differentiated cells on these surfaces at day 10. Statistical analyses of the (b) oil red O signal intensities obtained by spectrophotometry and the (c) FABP-4 marker gene expression obtained by quantitative PCR was performed and compared for these sample surfaces. The data bars represent the mean value $(n=3)$ and the standard deviation $( \pm S D)$ based on three independent experiments. The significance level ${ }^{* * *}$ stands for ${ }^{* * *} p<0.001$, and is shown by the results of the unpaired $t$-test.

The conjugation was attributed to the maleimide-equipped functionality, which was readily accessible to site-specific and covalent binding to thiol moieties through Michaeltype nucleophilic addition with high specificity and rapid kinetics under mild conditions at room temperature in aqueous solutions of $\mathrm{pH}$ 7.4. Such conjugation reactions have been shown to be successful without perturbing the protein structures or functions $[13,24,27]$. In addition, the covalent immobilization of the growth factors to biomaterial interfaces addresses challenges associated with delivering freely diffusible growth factors and has thus emerged as a promising method of achieving localized and sustained growth factor delivery based on a phenomenon called juxtracrine signaling (or contact-dependent signaling) $[3,28,29]$. Immobilized growth factors (i.e., BMP-2 and FGF-2) provide chemical cues for the guidance of stem cell behaviors and are therefore applicable to the material surface, where they demonstrate the concept. More importantly, both BMP-2 and FGF2 -functionalized surfaces can promote multilineage differentiation. However, only the FGF-2-functionalized surface had an enhanced effect on the normal growth of cultures, and this result is consistent with other publications. BMP-2, which belongs to the transforming growth factor beta (TGF- $\beta$ ) family, is now recognized as a multipurpose cytokine. When the chemical composition of the modified coatings and the conjugation reactions were confirmed, the current coating technique was also demonstrated to direct cellular activities for mesenchymal stem cells (MSCs) and induce BMP-2 function via activation of the SMAD signaling mechanism $[30,31]$, which leads to MSC multilineage differentiation that includes not only osteogenesis and chondrogenesis [32] but also adipogenesis [33-35]. On the other hand, FGF-2 has been shown to be part of a signaling pathway distinct from that of BMP-2 that enhances the self-renewal of MSCs such that they maintain their multilineage differentiation potential [36-38]. The coating material, poly- $p$-xylylene, is a highly biocompatible polymer of Class VI in the United States Pharmacopeia (USP), and the biocompatibility (or cell viability) examinations associated with the polymer system (thin films) or the same 
produced devices were well-reported during the past including biocompatibility against various types of cells (including hADSCs). The convincing results of stem cell differentiation in this report also clearly support the argument that the cells are alive, especially in the final stage of cell differentiation. Compared with committed or differentiated cells, the most fascinating feature of undifferentiated stem cells is their strong plasticity $[39,40]$, and the coating technology based on the proposed growth factor modifications by using vapor-phase maleimide-PPX can give full play to these characteristics of stem cells. The statistical quantification of these guided cellular activities and, for comparison, that of the pure maleimide-PPX coating surfaces and the unmodified TCPS control surfaces, is further analyzed and summarized in Table 2. These results clearly support that the surfacemodified products can promote the differentiation and proliferation of stem cells under various induction conditions, so as to achieve the expected effects for potential regenerative medicine applications.

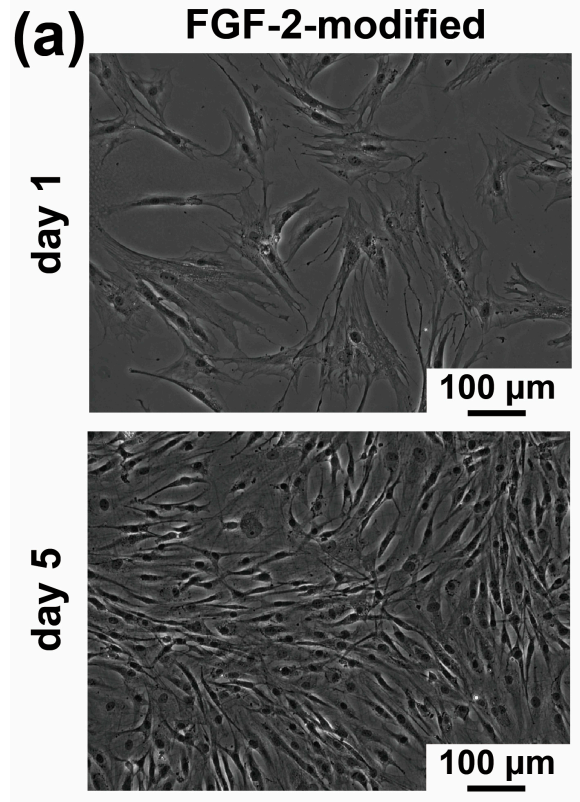

(b)

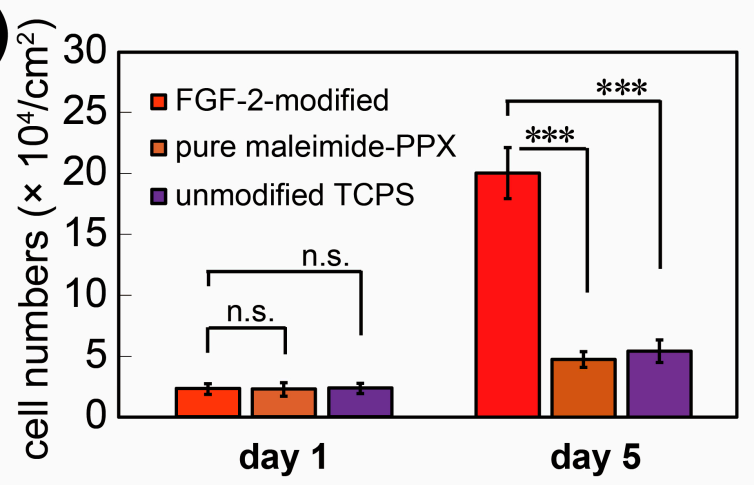

pure maleimide - PPX
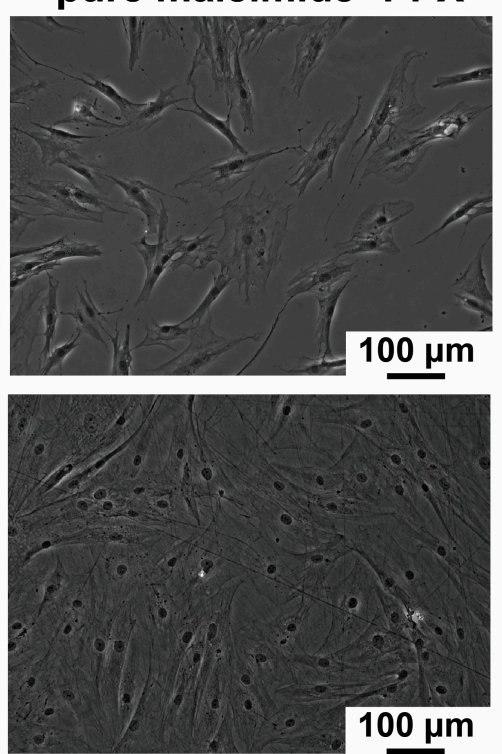

unmodified TCPS
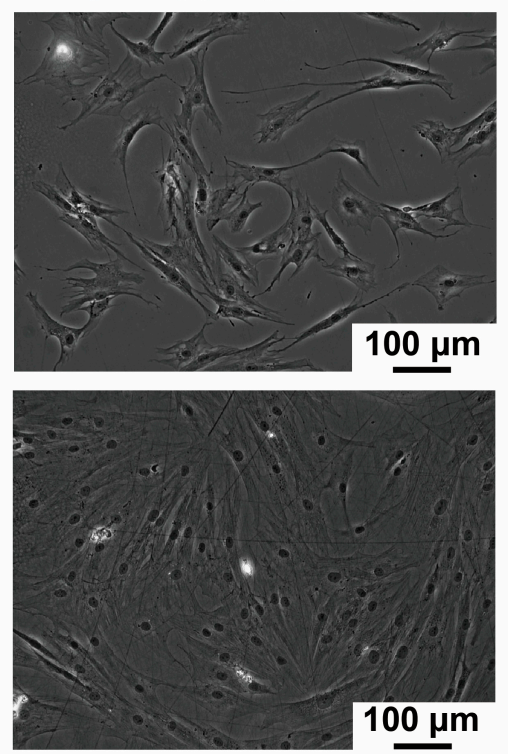

(c)

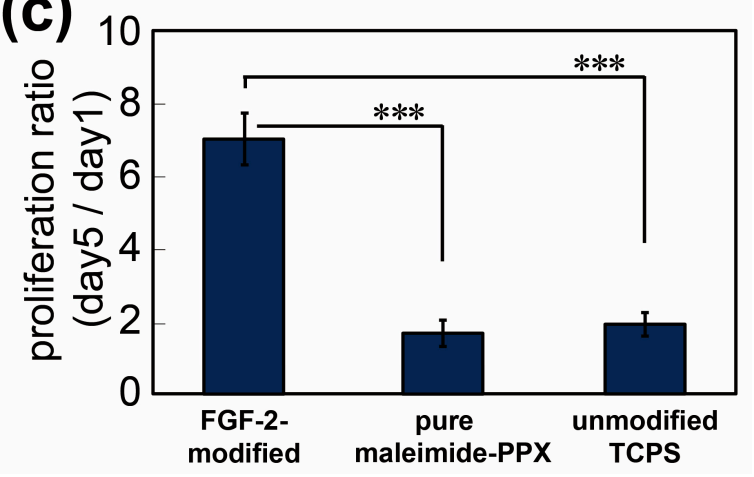

Figure 6. The proliferation activities of hADSCs were examined on the studied surfaces. (a) Phase-contrast micrographs of cell growth patterns recorded on day 1 and day 5. (b) Estimated cell numbers on day 1 and day 5 were compared for these surfaces. (c) The proliferation ratio that statistically normalized the cell numbers on day 5 to day 1 was compared for these studied surfaces. The data bars represent the mean value $(n=3)$ and the standard deviation $( \pm S D)$ based on three independent experiments. The significance levels n.s. and ${ }^{* *}$ stand for nonsignificant difference and ${ }^{* * *} p<0.001$, respectively, and are shown by the results of the unpaired $t$-test. 
Table 2. Enhanced induction properties of growth factor-modified surfaces based on the maleimide-functionalized poly- $p$ xylylene (maleimide-PPX) coating ${ }^{\mathrm{a}}$.

\begin{tabular}{|c|c|c|c|c|c|}
\hline Induction $^{b}$ & $\begin{array}{c}\text { BMP-2 } \\
\text { Modified }\end{array}$ & $\begin{array}{c}\text { FGF-2 } \\
\text { Modified }\end{array}$ & $\begin{array}{l}\text { Maleimide-PPX } \\
\text { Coating }\end{array}$ & $\begin{array}{l}\text { Unmodified } \\
\text { TCPS }\end{array}$ & $\begin{array}{c}\text { Potential } \\
\text { Applications }\end{array}$ \\
\hline osteogenesis & $277 \%$ & - & $108 \%$ & $100 \%$ & bone regeneration $[41,42]$ \\
\hline chondrogenesis & $156 \%$ & - & $100 \%$ & $100 \%$ & cartilage regeneration [43] \\
\hline adipogenesis & - & $172 \%$ & $94 \%$ & $100 \%$ & soft tissue reconstruction [44-46] \\
\hline proliferation & - & $378 \%$ & $94 \%$ & $100 \%$ & repair damage from wound or cuts [47] \\
\hline
\end{tabular}

${ }^{\text {a }}$ Data were normalized and compared against data from a control surface of commercially available tissue culture polystyrene (TCPS) plates. ${ }^{b}$ Data were compared and shown based on results from alizarin red staining, 1,9-dimethylmethylene blue staining, oil-red $\mathrm{O}$ staining, and cellular expansion rates.

\section{Conclusions}

In this study, an effective and general interface modification method for use in defining stem cell fate and enhancing the functions related to proliferation rate and multilineage differentiation capacity was demonstrated. The introduced surface modification was synthesized based on a clean and dry vapor deposition process that rendered a functional polymer coating. Most importantly, the facile integration of the maleimide functionality into the coating enabled the covalent conjugation of BMP-2 and FGF-2 growth factor proteins in mild conditions, which enabled guided differentiation and proliferation of the MSCs. With the proven concept that coating technology can be used not only on a variety of substrate materials, but also for conformity and stability on devices with sophisticated topology and geometry, we foresee that these findings have significant potential for further use in biomedical applications because of the various controllable parameters in favorable conditions offered by this coating technology.

Supplementary Materials: The following are available online at https:/ / www.mdpi.com/article/10 .3390/coatings11050582/s1, Figure S1: Maleimide-functionalized poly-p-xylylene (maleimide-PPX) coating. (a) Infrared reflec-tion-absorption spectroscopy (IRRAS) spectra for the maleimide-PPX coating. The peaks located at $1396 \mathrm{~cm}^{-1}(\mathrm{C}-\mathrm{N}), 1706$ and $1767 \mathrm{~cm}^{-1}(\mathrm{C}=\mathrm{O})$ correspond to the characteristic band stretches for the maleimide groups. Infrared reflection absorption spectroscopy (IRRAS) spectra for the Parylene-C coating which has no maleimide was also shown for the better comparison. (b) X-ray photoelectron spectroscopy (XPS) characterization of the maleimide-PPX coating. The table com-pares the experimental values of the XPS survey high-resolution C1 s spectra with the theoretical predictions. The signal at $285.0 \mathrm{eV}$ is attributed to the aliphatic and aromatic carbons $(\mathrm{C}-\mathrm{C}, \mathrm{C}-\mathrm{H})$, and the intensity at $84.5 \mathrm{at} \%$ compares well with the theoretical concentration of 84.2 at $\%$. The $\mathrm{C}-\mathrm{N}$ bond was detected with $5.6 \mathrm{at} \%$, which compares well with the theoretical value of 5.3 at $\%$. The peak at $288.6 \mathrm{eV}$ was assigned to the $\mathrm{O}=\mathrm{C}-\mathrm{N}$ group of the maleimide $(7.1 \mathrm{at} \%)$ and agrees with the theoretical value of 10.5 at $\%$. The signal at $291.4 \mathrm{eV}(2.8 \mathrm{at} \%)$ indicates $\pi \rightarrow \pi^{*}$ transitions, Figure S2: FT-IR spectra of BMP-2 (bone morphogenetic protein 2) and FGF-2 (fibroblast growth factor 2) alone. The thiol groups of the BMP-2 and FGF-2 proteins (i.e., S-H band at $2634 \mathrm{~cm}^{-1}$ ) in the spec-tra were highlighted, Figure S3: Biocompatibility analysis of the maleimide-PPX coatings. The human adipose-derived stem cells (hADSCs) were cultured on each surface for 1 day and the cell viabilities were then quantified by using a 3-(4,5-dimethylthiazol-2-yl)-2,5-diphenyltetrazolium bromide (MTT) assay. The data bars represent the mean value and the standard deviation $( \pm \mathrm{SD})$ based on three inde-pendent samples. The p-value large than 0.05 indicates the studied surface has a good biocom-patibility with no significant difference (n.s.) as compared to the unmodified TCPS surfaces. 
Author Contributions: Conceptualization, C.-Y.W., Y.-C.C. (Yu-Chih Chiang), Y.-C.Y., P.-C.C., P.-Y.W., and H.-Y.C.; methodology, C.-Y.W., Y.-C.C. (Yu-Chih Chiang), Y.-C.Y., P.-C.C., P.-Y.W. and H.-Y.C.; software, C.-Y.W., Y.-C.C. (Yu-Chih Chiang), Y.-C.C. (Yu-Chih Chiu), and Y.-C.Y.; validation, C.-Y.W., A.P.-H.H., and W.; formal analysis, C.-Y.W., J.C. and Y.-C.C. (Yu-Chih Chiu); investigation, Y.-C.C. (Yu-Chih Chiu), N.-Y.C. and Y.-C.Y., ; resources, P.-C.C., P.-Y.W., and H.-Y.C.; data curation, Y.-C.C. (Yu-Chih Chiang), A.P.-H.H. and W.; writing-original draft preparation, C.-Y.W., Y.-C.C. (Yu-Chih Chiang), P.-C.C., P.-Y.W. and H.-Y.C.; writing-review and editing, C.-Y.W., Y.-C.C. (Yu-Chih Chiang), P.-C.C., P.-Y.W. and H.-Y.C.; visualization, C.-Y.W., N.-Y.C. and J.C.; supervision, P.-C.C., P.-Y.W. and H.-Y.C.; project administration, P.-C.C., P.-Y.W. and H.-Y.C.; funding acquisition, P.-C.C., P.-Y.W. and H.-Y.C. All authors have read and agreed to the published version of the manuscript.

Funding: H.-Y.C. gratefully acknowledges support from the Ministry of Science and Technology of Taiwan (MOST 108-2221-E-002-169-MY3). P.-C.C. gratefully acknowledges support from the Ministry of Science and Technology of Taiwan (MOST 107-2221-E-027-009-MY2; 108-2321-B-010-008-MY2). P.-Y.W. acknowledges the support from the National Key Research and Development Program of China (2018YFC1105201), the National Natural Science Foundation of China. This work was further supported by the "Advanced Research Center For Green Materials Science and Technology" from The Featured Area Research Center Program within the framework of the Higher Education Sprout Project by the Ministry of Education (107L9006) and the Ministry of Science and Technology in Taiwan (MOST 107-3017-F-002-001).

Institutional Review Board Statement: Not applicable.

Informed Consent Statement: Not applicable.

Data Availability Statement: All data generated or analyzed during this study are included in this published article and its supplementary information files.

Conflicts of Interest: The authors declare no competing financial interests. The funders had no role in the design of the study; in the collection, analyses, or interpretation of data; in the writing of the manuscript, or in the decision to publish the results.

$\begin{array}{ll}\text { Abbreviations } & \\ \text { PPX } & \text { Poly-p-xylylene } \\ \text { BMP-2 } & \text { Bone Morphogenetic Protein 2 } \\ \text { FGF-2 } & \text { Fibroblast Growth Factor 2 } \\ \text { hADSCs } & \text { Human Adipose-Derived Stem Cells } \\ \text { CVD } & \text { Chemical Vapor Deposition } \\ \text { Maleimide-PPX } & \text { Poly[(4-N-maleimidomethyl- } p \text {-xylylene)-co(p-xylylene)] } \\ \text { TGF- } \beta & \text { Transforming Growth Factor Beta } \\ \text { MSCs } & \text { Mesenchymal Stem Cells } \\ \text { FT-IR } & \text { Fourier Transform Infrared } \\ \text { XPS } & \text { X-ray Photoelectron Spectroscopy } \\ \text { DTT } & \text { Dithiothreitol } \\ \text { QCM } & \text { Quartz Crystal Microbalance } \\ \mu C P & \text { Microcontact Printing } \\ \text { PDMS } & \text { Poly(dimethylsiloxane) } \\ \text { TCPS } & \text { Tissue Culture Polystyrene } \\ \text { ALP } & \text { Alkaline Phosphatase } \\ \text { ARS } & \text { Alizarin Red S } \\ \text { sGAG } & \text { Sulfated Glycosaminoglycan } \\ \text { DMMB } & \text { 1,9-Dimethylmethylene Blue } \\ \text { FABP-4 } & \text { Fatty Acid-Binding Protein 4 } \\ \text { MTT } & \text { 3-(4,5-Dimethylthiazol-2-yl)-2,5-diphenyltetrazolium Bromide } \\ \text { qPCR } & \text { Quantitative Real-Time Polymerase Chain Reaction }\end{array}$




\section{References}

1. Ito, Y.; Tada, S. Bio-orthogonal and combinatorial approaches for the design of binding growth factors. Biomaterials 2013, 34, 7565-7574. [CrossRef]

2. Fu, R.H.; Wang, Y.C.; Liu, S.P.; Huang, C.M.; Kang, Y.H.; Tsai, C.H.; Shyu, W.C.; Lin, S.Z. Differentiation of stem cells: Strategies for modifying surface biomaterials. Cell Transplant. 2011, 20, 37-47. [CrossRef]

3. Masters, K.S. Covalent growth factor immobilization strategies for tissue repair and regeneration. Macromol. Biosci. 2011, 11, 1149-1163. [CrossRef]

4. Kusamori, K.; Takayama, Y.; Nishikawa, M. Stable Surface Modification of Mesenchymal Stem Cells Using the Avidin-Biotin Complex Technique. Curr. Protoc. Stem Cell Biol. 2018, 47, e66. [CrossRef] [PubMed]

5. Sengupta, P.; Prasad, B.L.V. Surface Modification of Polymers for Tissue Engineering Applications: Arginine Acts as a Sticky Protein Equivalent for Viable Cell Accommodation. ACS Omega 2018, 3, 4242-4251. [CrossRef] [PubMed]

6. Mahla, R.S. Stem Cells Applications in Regenerative Medicine and Disease Therapeutics. Int. J. Cell Biol. 2016, $2016,6940283$. [CrossRef] [PubMed]

7. Gimble, J.M.; Katz, A.J.; Bunnell, B.A. Adipose-derived stem cells for regenerative medicine. Circ. Res. 2007, 100, 1249-1260. [CrossRef] [PubMed]

8. Dellatore, S.M.; Garcia, A.S.; Miller, W.M. Mimicking Stem Cell Niches to Increase Stem Cell Expansion. Curr. Opin. Biotechnol. 2008, 19, 534-540. [CrossRef]

9. Lu, Z.; Roohani-Esfahani, S.I.; Wang, G.; Zreiqat, H. Bone Biomimetic Microenvironment Induces Osteogenic Differentiation of Adipose Tissue-derived Mesenchymal Stem Cells. Nanomedicine 2012, 8, 507-515. [CrossRef]

10. Donnelly, H.; Salmeron-Sanchez, M.; Dalby, M.J. Designing Stem Cell Niches for Differentiation and Self-renewal. J. R. Soc. Interface 2018, 15, 20180388. [CrossRef] [PubMed]

11. Chen, H.-Y.; Lahann, J. Designable Biointerfaces Using Vapor-Based Reactive Polymers. Langmuir 2010, 27, 34-48. [CrossRef]

12. Sun, H.-Y.; Fang, C.-Y.; Lin, T.-J.; Chen, Y.-C.; Lin, C.-Y.; Ho, H.-Y.; Chen, M.H.C.; Yu, J.; Lee, D.-J.; Chang, C.-H.; et al. Thiol-Reactive Parylenes as a Robust Coating for Biomedical Materials. Adv. Mater. Interfaces 2014, 1. [CrossRef]

13. Tsai, Y.-T.; Wu, C.-Y.; Guan, Z.-Y.; Sun, H.-Y.; Cheng, N.-C.; Yeh, S.-Y.; Chen, H.-Y. Topologically Controlled Cell Differentiation Based on Vapor-Deposited Polymer Coatings. Langmuir 2017, 33, 8943-8949. [CrossRef] [PubMed]

14. Lahann, J.; Langer, R. Novel Poly(p-xylylenes): Thin Films with Tailored Chemical and Optical Properties. Macromolecules 2002, 35, 4380-4386. [CrossRef]

15. Sauerbrey, G. Verwendung von Schwingquarzen zur Wägung dünner Schichten und zur Mikrowägung. Z. Phys. 1959, 155, $206-222$. [CrossRef]

16. Wu, C.-Y.; Liu, H.-Y.; Huang, C.-W.; Yeh, S.-Y.; Cheng, N.-C.; Ding, S.-T.; Chen, H.-Y. Synergistically Controlled Stemness and Multilineage Differentiation Capacity of Stem Cells on Multifunctional Biointerfaces. Adv. Mater. Interfaces 2017, 4, 1700243. [CrossRef]

17. Zheng, C.H.; Levenston, M.E. Fact versus artifact: Avoiding erroneous estimates of sulfated glycosaminoglycan content using the dimethylmethylene blue colorimetric assay for tissue-engineered constructs. Eur. Cells Mater. 2015, 29, 224-236. [CrossRef]

18. Kraus, N.A.; Ehebauer, F.; Zapp, B.; Rudolphi, B.; Kraus, B.J.; Kraus, D. Quantitative assessment of adipocyte differentiation in cell culture. Adipocyte 2016, 5, 351-358. [CrossRef]

19. Zuk, P.A.; Zhu, M.; Ashjian, P.; De Ugarte, D.A.; Huang, J.I.; Mizuno, H.; Alfonso, Z.C.; Fraser, J.K.; Benhaim, P.; Hendrick, M.H. Human Adipose Tissue is a Source of Multipotent Stem Cells. Mol. Biol. Cell 2002, 13, 4279-4295. [CrossRef]

20. Livak, K.J.; Schmittgen, T.D. Analysis of relative gene expression data using real-time quantitative PCR and the 2(-Delta Delta C(T)) Method. Methods 2001, 25, 402-408. [CrossRef]

21. Tsai, M.-Y.; Lin, C.-Y.; Huang, C.-H.; Gu, J.-A.; Huang, S.-T.; Yu, J.; Chen, H.-Y. Vapor-based synthesis of maleimide-functionalized coating for biointerface engineering. Chem. Commun. 2012, 48, 10969-10971. [CrossRef]

22. Hoyle, C.E.; Bowman, C.N. Thiol-ene click chemistry. Angew. Chem. Int. Ed. Engl. 2010, 49, 1540-1573. [CrossRef] [PubMed]

23. Brewer, C.F.; Riehm, J.P. Evidence for possible nonspecific reactions between N-ethylmaleimide and proteins. Anal. Biochem. 1967, 18, 248-255. [CrossRef]

24. Chen, Y.C.; Sun, T.P.; Su, C.T.; Wu, J.T.; Lin, C.Y.; Yu, J.; Huang, C.W.; Chen, C.J.; Chen, H.Y. Sustained immobilization of growth factor proteins based on functionalized parylenes. ACS Appl. Mater. Interfaces 2014, 6, 21906-21910. [CrossRef] [PubMed]

25. Wu, J.-T.; Sun, T.-P.; Huang, C.-W.; Su, C.-T.; Wu, C.-Y.; Yeh, S.-Y.; Yang, D.-K.; Chen, L.-C.; Ding, S.-T.; Chen, H.-Y. Tunable coverage of immobilized biomolecules for biofunctional interface design. Biomater. Sci. 2015, 3, 1266-1269. [CrossRef]

26. Della Ventura, B.; Sakac, N.; Funari, R.; Velotta, R. Flexible immunosensor for the detection of salivary alpha-amylase in body fluids. Talanta 2017, 174, 52-58. [CrossRef] [PubMed]

27. Sun, T.P.; Tai, C.H.; Wu, J.T.; Wu, C.Y.; Liang, W.C.; Chen, H.Y. Multifaceted and route-controlled click reactions based on vapor-deposited coatings. Biomater. Sci. 2016, 4, 265-271. [CrossRef]

28. Pagán, M.; Suazo, D.; Del Toro, N.; Griebenow, K. A Comparative Study of Different Protein Immobilization Methods for the Construction of an Efficient Nano-structured Lactate Oxidase-SWCNT-biosensor. Biosens. Bioelectron. 2015, 64, 138-146. [CrossRef] [PubMed]

29. Chou, C.H.; Modo, M. Human neural stem cell-induced endothelial morphogenesis requires autocrine/paracrine and juxtacrine signaling. Sci. Rep. 2016, 6, 29029. [CrossRef] 
30. Shi, Y.; Massagué, J. Mechanisms of TGF- $\beta$ Signaling from Cell Membrane to the Nucleus. Cell 2003, 113, 685-700. [CrossRef]

31. Mueller, T.D. Chapter One-Mechanisms of BMP-Receptor Interaction and Activation. In Vitamins \& Hormones; Litwack, G., Ed.; Academic Press: Los Angeles, CA, USA, 2015; Volume 99, pp. 1-61.

32. Shea, C.M.; Edgar, C.M.; Einhorn, T.A.; Gerstenfeld, L.C. BMP Treatment of C3H10T1/2 Mesenchymal Stem Cells Induces Both Chondrogenesis and Osteogenesis. J. Cell. Biochem. 2003, 90, 1112-1127. [CrossRef]

33. Lee, S.Y.; Lee, J.H.; Kim, J.Y.; Bae, Y.C.; Suh, K.T.; Jung, J.S. BMP2 increases adipogenic differentiation in the presence of dexamethasone, which is inhibited by the treatment of TNF-alpha in human adipose tissue-derived stromal cells. Cell. Physiol. Biochem. 2014, 34, 1339-1350. [CrossRef] [PubMed]

34. Sottile, V.; Seuwen, S. Bone morphogenetic protein-2 stimulates adipogenic dijerentiation of mesenchymal precursor cells in synergy with BRL 49653 (rosiglitazone). FEBS Lett. 2000, 475, 201-204. [CrossRef]

35. Vanhatupa, S.; Ojansivu, M.; Autio, R.; Juntunen, M.; Miettinen, S. Bone Morphogenetic Protein-2 Induces Donor-Dependent Osteogenic and Adipogenic Differentiation in Human Adipose Stem Cells. Stem Cells Transl. Med. 2015, 4, 1391-1402. [CrossRef] [PubMed]

36. Chiou, M.; Xu, Y.; Longaker, M.T. Mitogenic and Chondrogenic Effects of Fibroblast Growth Factor-2 in Adipose Derived Mesenchymal Cells. Biochem. Biophys. Res. Commun. 2006, 343, 644-652. [CrossRef]

37. Hankemeier, S.; Keus, M.; Zeichen, J.; Jagodzinski, M.; Barkhausen, T.; Bosch, U.; Krettek, C.; Van Griensven, M. Modulation of Proliferation and Differentiation of Human Bone Marrow Stromal Cells by Fibroblast Growth Factor 2: Potential Implication for Tissue Engineering of Tendons and Ligaments. Tissue Eng. 2005, 11, 41-49. [CrossRef] [PubMed]

38. Kakudo, N.; Shimotsuma, A.; Kusumoto, K. Fibroblast Growth Factor-2 Stimulates Adipogenic Differentiation of Human Adipose-derived Stem Cell. Biochem. Biophys. Res. Commun. 2007, 395, 239-244. [CrossRef]

39. Merrell, A.J.; Stanger, B.Z. Adult cell plasticity in vivo: De-differentiation and transdifferentiation are back in style. Nat. Rev. Mol. Cell Biol. 2016, 17, 413-425. [CrossRef]

40. Chiacchiera, F.; Morey, L.; Mozzetta, C. Editorial: Epigenetic Regulation of Stem Cell Plasticity in Tissue Regeneration and Disease. Front. Cell Dev. Biol. 2020, 8, 82. [CrossRef]

41. Hernigou, P.; Poignard, A.; Beaujean, F.; Rouard, H. Percutaneous Autologous Bone-Marrow Grafting for Nonunions: Influence of the Number and Concentration of Progenitor Cells. JBJS 2005, 87, 1430-1437. [CrossRef]

42. Giuliani, N.; Lisignoli, G.; Magnani, M.; Racano, C.; Bolzoni, M.; Dalla Palma, B.; Spolzino, A.; Manferdini, C.; Abati, C.; Toscani, D.; et al. New Insights into Osteogenic and Chondrogenic Differentiation of Human Bone Marrow Mesenchymal Stem Cells and Their Potential Clinical Applications for Bone Regeneration in Pediatric Orthopaedics. Stem Cells Int. 2013, 2013 , 312501. [CrossRef]

43. Chen, H.; Wang, H.; Li, B.; Feng, B.; He, X.; Fu, W.; Yuan, H.; Xu, Z. Enhanced chondrogenic differentiation of human mesenchymal stems cells on citric acid-modified chitosan hydrogel for tracheal cartilage regeneration applications. RSC Adv. 2018, 8, 16910-16917. [CrossRef]

44. Tan, S.S.; Ng, Z.Y.; Zhan, W.; Rozen, W. Role of Adipose-derived Stem Cells in Fat Grafting and Reconstructive Surgery. J. Cutan. Aesthet. Surg. 2016, 9, 152-156. [CrossRef] [PubMed]

45. Yoshimura, K.; Sato, K.; Aoi, N.; Kurita, M.; Inoue, K.; Suga, H.; Eto, H.; Kato, H.; Hirohi, T.; Harii, K. Cell-assisted lipotransfer for facial lipoatrophy: Efficacy of clinical use of adipose-derived stem cells. Dermatol. Surg. 2008, 34, 1178-1185. [CrossRef]

46. Yoshimura, K.; Sato, K.; Aoi, N.; Kurita, M.; Hirohi, T.; Harii, K. Cell-assisted lipotransfer for cosmetic breast augmentation: Supportive use of adipose-derived stem/stromal cells. Aesthetic Plast. Surg. 2008, 32, 48-57. [CrossRef] [PubMed]

47. Cooper, G.M. The Cell: A Molecular Approach, 2nd ed.; Sinauer Associates: Sunderland, MA, USA, 2000. 